\title{
EXORDIUM
}

\section{ACTIVE SURVEILLANCE AS A COLLATERAL PRACTICE OF CONTEMPORARY PEDAGOGICAL DEVICES OF THE PRESENT TIME}

\author{
LA SORVEGLIANZA ATTIVA COME PRATICA \\ COLLATERALE DEI DISPOSITIVI PEDAGOGICI \\ CONTEMPORANEI DEL TEMPO PRESENTE
}

di Carla Cardinaletti (Free University of Bozen)

«A collateral victim» ${ }^{1}$ of the Spanish flu epidemic: these are the words that Edgar Morin (2020) uses to define himself in his Preamble: One bundred years of vicissitudes, written during the lockdown imposed to stem the spread of Covid-19. Over a handful of pages, the French philosopher and sociologist gives a first-person account of his own personal life in relation to the history of the great crises of the $20^{\text {th }}$ Century. His preamble to the book Let's change lanes: Lessons of Coronavirus reads as follows: «The reader can now understand why I find it normal to expect the unexpected and to foresee that the unpredictable may happen» ${ }^{2}$ (Morin, 2020, p. 22). Over the course of the text, Morin's readers are also brought to understand why the author has not «completely lost hope» (Morin, 2020, p. 22).

Hence, the beauty of the words of Morin, as a «transversal thinker» (Montuori, 2019, p. 408), is collateral: his lucid analysis does indeed retrace the catastrophic events that have arisen during the pandemic, underlining human beings' predisposition to dystopian attitudes, yet it simultaneously highlights key steps towards fostering that humanism necessary to change the path.

${ }^{1}$ Original text: "Vittima collaterale".

2 Original text: "Il lettore può capire ora perché trovo normale aspettarmi l'inatteso e prevedere che l'imprevedibile possa accadere". 
If aesthetics, according to the definition given by its founder Baumgarten (1750), is the «sensory theory» ${ }^{3}$ (Tedesco, 2020, p. 9), perhaps the key to grasping the collateral beauty of adverse events lies in implementing knowledge of sensibilities, i.e. that ability to envisage the unexpected (Morin, 2001; 2020), to understand that pain is part of life (Han, 2020), to think emotions, feel thoughts ${ }^{4}$ (Mortari, 2017), to listen to the Other because it concerns us (Levinas, 2002).

This contribution aims to relate some findings of contemporary Italian pedagogy, which, in response to the Covid-19 crisis, are exploring those sensibilities able to deal with the unexpected, considering the concepts of uncertainty, margin and care from a phenomenological perspective (Mortari \& Camerella, 2014). Educational practices, brought to the fore by the academic community in the field of education, become an active surveillance tool to provide a response to current issues that is not only theoretical, but also empirical and «operational» ${ }^{5}-$ i.e. «capable of directing and orienting its choices in a strategic way in contexts where highly critical situations occur» (Isidori \& Vaccarelli, 2013, pp. 16-17).

«Vittima collaterale» dell'epidemia influenzale spagnola. Così si definisce Edgar Morin (2020) nel suo Preambolo Cent'anni di vicissitudini, scritto durante il lockdown da Covid-19. Il filosofo, sociologo francese ripercorre in una manciata di pagine, attraverso il racconto in prima persona, la sua storia e quella delle grandi crisi del Novecento. La chiosa personale al suo breve testo introduttivo al saggio Cambiamo strada. Le 15 lezioni del Coronavirus così recita: «Il lettore può capire ora perché trovo normale aspettarmi l'inatteso e prevedere che l'imprevedibile possa accadere» (Morin, 2020, p. 22). Proseguendo con la lettura, capirà anche perché l'autore non abbia perso «del tutto la speranza» (Morin, 2020, p. 22).

3 Original text: "Scienza della conoscenza sensibile".

${ }^{4}$ Subtitle of Mortari's book (original text): "La sapienza del cuore. Pensare le emozioni, sentire ipensiern".

${ }^{5}$ Original text: "Operativa", "capace di indirizzare e orientare le sue scelte in modo strategico in contesti in cui si verificano situazioni fortemente critiche". 
Collaterale è, dunque, la bellezza delle parole del «transversal thinker» Morin (Montuori, 2019, p. 408): la sua analisi lucida ripercorre sì gli eventi catastrofici legati al periodo pandemico sottolineando gli atteggiamenti distopici dell'essere umano, ma - al contempo - mette in luce i passaggi chiave per attuare quell'umanesimo necessario per cambiare strada.

Se l'estetica, seguendo la definizione del suo fondatore Baumgarten (1750), è la «scienza della conoscenza sensibile» (Tedesco, 2020, p. 9), forse la chiave per afferrare la bellezza collaterale degli eventi avversi risiede nell'implementare la conoscenza delle sensibilità, vale a dire quella capacità di cogliere l'inatteso (Morin, 2001; 2020), di comprendere che il dolore è parte della vita (Han, 2020), di pensare le emozioni, sentive ipensieri ${ }^{6}$ (Mortari, 2017), di ascoltare l'altro, perché ci riguarda (Levinas, 2002).

Questo contributo ha l'ambizione di mettere in relazione alcune esperienze della pedagogia contemporanea italiana, che, a fronte dell'emergenza pandemica, stanno esplorando quelle sensibilità capaci di fronteggiare l'imprevisto, maneggiare il concetto di incertezza, di margine e di cura in un'ottica fenomenologica (Mortari \& Camerella, 2014). Le pratiche educative, che il mondo della formazione sta mettendo in atto, divengono uno strumento di sorveglianza attiva per dare una risposta al tempo presente non solo teorica, ma anche empirica e «operativa» - vale a dire - «capace di indirizzare e orientare le sue scelte in modo strategico in contesti in cui si verificano situazioni fortemente critiche» (Isidori \& Vaccarelli, 2013, pp. 16-17).

\section{Introduction}

The aim of this paper is twofold. On one hand, it provides an overview of the extensive academic output from Italian scholars in the field of pedagogy and the social sciences during the Covid-19 pandemic. On the other, it highlights some key contributions that

${ }^{6}$ Sottotitolo del libro di Mortari: La sapienza del cuore. 
placed emphasis on the collateral beauty of the present time. This manifold output is evidence of an acute awareness on the part of the academic community in the humanities as to the paradigm shift that the pandemic is causing within all our societies. Though this compilatory review does not set out to be exhaustive, it considers more than 5,000 pages published by Italian authors between spring 2020 and summer 2021.

Firstly, this paper sets out the theoretical context of the literature review, clarifying the epistemological choices that determined the reported bibliography; secondly, the study explains methodological processes undertaken in order to list and organise the contributions examined; thirdly, it proposes an overview of a reasoned bibliography divided into key categories; in conclusion, it sums up the main concepts that show Italian scholars' engagement in tracing new paths «chang[ing] lanes» ${ }^{7}$ (Morin, 2020, p. 67), and a «change of pace» (Contini, 2021, p. 13).

\section{Theoretical context}

If it is in plain sight that pure and applied science scholars in the fields of biology, medicine and health and healing branches worked diligently on the discovery of practical devices for coping with the pandemic, the intense engagement of many academics in the humanities seems to have passed comparatively unnoticed. Therefore, this paper has the purpose of shedding some light on the crucial role of the human sciences as a driving force in these times of uncertainty. We need not only to seek a balance with the new virus in biological and species terms, but also from a social, cultural and economic perspective (Bertagna, 2020). Hence, education assumes a pivotal role insofar as «it is fundamental to care for the present and

${ }^{7}$ Original text: "Cambiamo strada". 
to defend the future, since action today has repercussions and consequences extending into the future» ${ }^{8}$ (Mariani, 2021, p. 50).

The richness of the proposals considered lies in the diversity of their authors' backgrounds, which serve to demonstrate their collective ability to weave that common thread of the collateral beauty of the pandemic period in complex plots. While aiming to delimit the scope of the numerous scientific studies on the topic of education, the search for sources has necessarily extended to neighbouring sciences, often spilling into sociology, psychology, philosophy and, at times, economics, computer science and health. Hence, answering the questions «Where does pedagogy live? [...] What is pedagogy about?» ${ }^{9}$, Annacontini \& Dato point out its status as «hybridised science ${ }^{10}$, understanding its crucial role as a device able to unite the pivotal dimensions of a human being's life, such as its generativity and evolution (2020, p. VII).

The boundaries of pedagogy, understood as «knowledge of knowledges» ${ }^{11}$ (Dozza, 2020, p. 11) and, in this context, a «border science among multiple crises» ${ }^{12}$ (Mannese, 2021, p. 276) are indistinct. Therefore, this review goes beyond the status imposed by labels within the Italian academy, looking instead at the phenomenon of this literature review in dialogic terms (Morin, 2021b), with a mindset of discovery and guided by the teachings of «mentor» ${ }^{13}$ (Annacontini, 2021, p. 78) Edgar Morin.

The guidelines elaborated by the centenarian «transversal thinker» (Montuori, 2019, p. 408) in his brilliant Lessons of the Coronavirus were taken as a compass and a "polar star» ${ }^{14}$ (Cambi, 2021, p. 133) in selecting contributions listed in this paper. Although Morin

${ }^{8}$ Original text: "Poiché essa si rivela fondamentale per la cura del presente e per la difesa dell'avvenire, giacché l'azione di oggi ha ripercussioni e conseguenze dilatate nel tempo futuro".

9 Original text: "Dove abita la pedagogia? Di cosa si occupa la pedagogia?"

${ }^{10}$ Original text: "Scienza ibridativa".

11 Original text: "Sapere dei saperi".

${ }^{12}$ Original text: "Scienza di confine tra molteplici crisi".

13 Original text: "Mentore".

${ }^{14}$ Original text: "Stella polare". 
(2000; 2020; 2021a; 2021b) has called in his philosophy for an ecological approach to phenomena, the most suitable way to report the findings of this review seemed to be to compile them into a reasoned bibliography. This choice could be deemed an oxymoron in the light of theories of complexity; however, as Harris (2020) suggests, «breaking down complex arguments can often be useful» ( $p$. $60)$ as a means to provide the reader with an overview of the main topics examined.

Thus, this study shall report contributions pertaining to the following subjects: the pedagogy of emergency, care and hope; «alleanza educativa» (Gigli, 2021, p. 15) - i.e. the relationship between families, teachers and educators -; the use of technologies in educational contexts; explorations of emotions and skills; disability studies; surveys of student conditions; the roles of families and caregivers; sociological impacts; etc. Furthermore, scholars in the social sciences not only wrote about the pandemic, but pursued theoretical reflections as a general tool for coping with this unexpected global disruption. In this sense, many contributions cited serve to delineate the context of the discourse insofar as they pertain to pedagogical reflections. These shall be excluded from the annotated bibliography as they are already included within the reference list.

\section{Methodological considerations}

The present research was divided into three phases: the first involved data collection, the second organisation of contributions and the last analysis of these in order to establish the main categories of topics investigated by the authors. As a qualitative methodological inquiry, this study relies on an interpretative phenomenological approach, as explained by Mortari (2008; 2019). Since the author is a member of the Italian academic community, situated at a time when the disruptions of the pandemic are ongoing, it was fundamental to enact the epoché process, as propounded by Husserl (2004). Bracketing «the fullness of mind» (Mortari, 2019, p. 50) and «being faithful to the phenomenon» (Mortari, 2008, p. 4) is the means to defuse 
«habitual epistemic tools: conceptual webs, sets of theories, procedural rules» (Mortari, 2008, p. 4).

\section{Data collection.}

An analogical method was used to seek out the Italian contributions, i.e. searching for publishers' websites directly, following the hierarchy of sources shared by academics: monographs, essay collections, academic journals (Range A, area 11, as reported by Anvur), studies published by universities, conference and pedagogical society reports. Use of web search engines was avoided in order to limit the risk of potential bias arising from the automatic function of crawlers. Evidently, this review may not be exhaustive and it will certainly miss some contributions; however, outlining the methodology used in data collection should be useful to monitor the scientific reliability.

\section{Organization of contributions.}

The literature review considers contributions published - either in print or online (almost all with doi) - between spring 2020 and mid-summer 2021, by authors working within the Italian academic community. The result of this research is a list of 248 contributions written during the following periods:

- $\quad 91$ contributions in 2020

- 157 contributions in 2021

Of these contributions, 121 were published in books, whether online or printed (including 15 written by a single author), 92 are academic papers (Rank A, Anvur ${ }^{15}$ ) and 20 are articles (not Rank A, Anvur). In addition, the review considers 11 studies undertaken by universities and four by research institutes credited by Italian institutions. 
Analysis.

On account of the volume of the output, a semantic analysis of the contributions' titles was conducted with the aid of a $C A Q D A S^{16}$ digital qualitative analysis tool in order to track a general overview of the topics examined. The words Covid/Covid-19 (weighted percentage $3,40 \%$ ) and Coronavirus (weighted percentage $0,51 \%$ ) were excluded from the analysis. A limitation of this practice lies in the prevalence of evocative headlines in Italian academic writing. An example is this brilliant wordplay by Gigli (2021): Anticorpi pedagogici, a chapter heading for contributions published in the fourth part of the book Oltre l'emergenza. Sguardi pedagogici su infanzia, famiglie, servizi educativi e scolastici nel Covid-19.

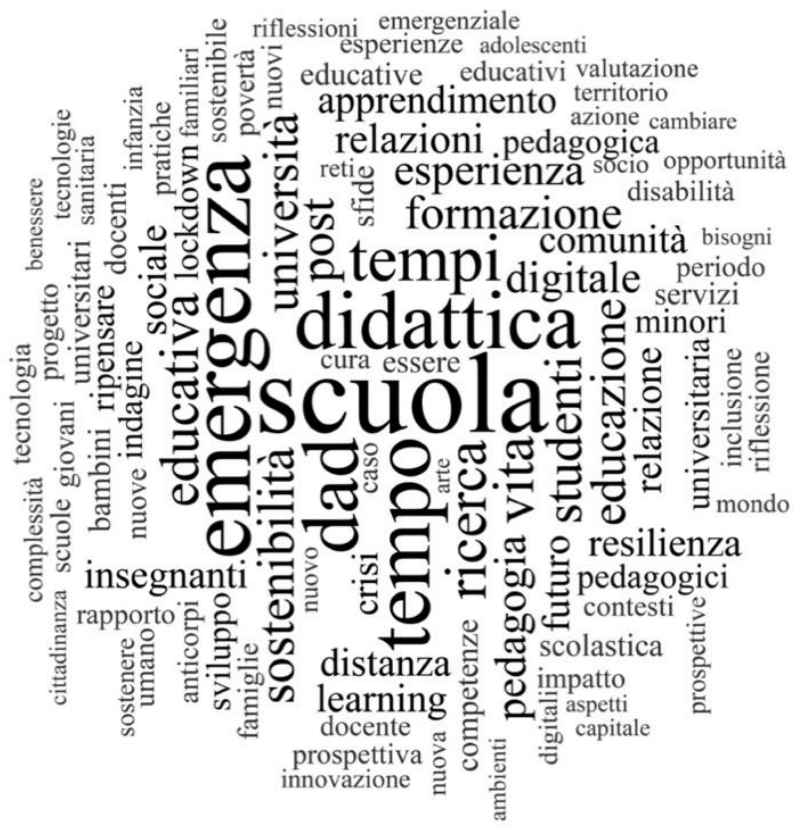

Word cloud generated by the author ${ }^{17}$.

16 "Computer Assisted Qualitative Data Analysis Software" (Seale, 2002, p. 224).

${ }^{17}$ The semantic analysis only considered nouns, adjectives and verbs in the infinitive. "Didattica a distanza" was considered as $\mathrm{DaD}$, since the software only allows for single-word and not collocation searches. 
Unfortunately, a semantic analysis could not be conducted on the contents of the contributions themselves, since a third are exclusively available in printed publications. The richness and variety of proposals is of course broader; however, as demonstrated in the table above, word frequency provided a first glimpse of the main topics. Some of the words were clustered into broader categories, after a qualitative analysis relating the contents of the most significant contributions to Morin's teachings.

\section{Reasoned bibliography}

Following Harris' guidelines (2020) regarding the management of sources, «it is useful to be able to manage complexity by separating out different ideas that are working together in the literature you read» (p. 60). Thus, in this section, the main subject areas investigated shall be reported, with the related list of sources in alphabetical order. The aim is «to indicate some useful paths for the scholar and the student ${ }^{18}$, as introduced by Mariani Zini (2009, p. 373) and displayed by Mortari \& Mazzoni (2010) in their significant reasoned bibliographies on the respective topics of aesthetics and pedagogical research for children.

\section{Schools and the pandemic}

Bertagna G. (2020). La scuola al tempo del Covid. Tra spazio di esperienza ed orizzonte d'attesa. Roma: Studium Edizioni.

Dello Preite F. (2021). Dirigere le scuole durante il Covid-19: esiti di un'indagine qualitativa a livello nazionale. Formazione \& Insegnamento, 19(III), 417-426. doi: 10.7346/-fei-XIX-01-21_36

Gavosto A. (2020). Scuola e capitale umano. In Laterza (Ed.), Il mondo dopo la fine del mondo (pp. 234-249). Roma: Laterza.

${ }^{18}$ Original text: "Di indicare alcuni percorsi utili allo studioso, e allo studente". 
Mesa D., \& Triani P. (2021). Ripensare la scuola nell'epoca del Coronavirus. In Istituto Giuseppe Toniolo, La condizione giovanile in Italia. Rapporto Giovani 2021 (pp. 23-56). Bologna: Il Mulino. doi: $10.978 .8815 / 366887$.

Mortari L. (2021) (Ed). La scuola del Covid-19: i vissuti dei docenti. Verona: Edizioni Universitarie Cortina.

Roncaglia G. (2020). Pandemia e scuola. In Laterza (Ed.), Il mondo dopo la fine del mondo (pp. 415-425). Roma: Laterza.

Tonucci F. (2020). Pù un virus cambiare la scuola?. Città di Castello: Zeroseiup.

Universities: students, professors \& studies

Cardano M., Scavarda A., \& Tomatis F. (2021). La fatica di essere - comunque - sè stessi. La salute mentale e la qualità della vita degli studenti universitari durante la pandemia. In A.R. Favretto, A. Maturo \& S. Tomelleri (Eds.), L'impatto sociale del Covid-19 (pp. 341-351). Milano: FrancoAngeli.

Monteduro G. (2021) (Ed.). Sotto esame. La vita degli studenti universitari al tempo del Covid-19. Trento: Erickson.

Longo L., Gülbay E., \& Di Carlo D.R. (2021). Valutazione formativa e didattica a distanza all'Università. Annali online della Didattica e della Formazione Docente, 13(21), 199-214.

Antonacci F., Gambacorti-Passerini M.B., \& Guerra M. (2021). Dialoghi tra Università e Cittadinanza: un contributo pedagogico per sostenere le azioni educative in tempo di emergenza pandemica. Lifelong Lifewide Learning, 17(38), 54-62.

Montanari M., \& Costantini M. (2021). L'educatore socio-pedagogico tra pratiche di cura e tirocinio. Lifelong Lifewide Learning, 17(38), 83-94.

$\mathrm{DaD}$

Agrati L.S. (2021). L'emergenza da coronavirus come verifica delle competenze digitali dei docenti. Indagine sulla pregressa formazione in servizio. Formazione \& Insegnamento, 19(2), 179-192. doi: 10.7346/-feiXIX-02-21_17.

Aroldi P. (2021). Considerazioni sulla DAD e sulle lezioni durante il lockdown 2020. In M. Sala (Ed.), Libro Bianco. Media e minori. L'educazione ai nuovi media ai tempi del coronavirus (pp. 119-122). Soveria Mannelli: Rubettino. 
Baldacci M. (2020). La pandemia e la didattica a distanza. Pedagogia più Didattica, 6(2), 1-3.

Bellantonio S. (2020). Corpo e spazio nella didattica a distanza. Ossimoro o chance educativa. Giornale Italiano di Educazione alla Salute, Sport e Didattica Inclusiva, 4, 45-51. doi: https://doi.org/10.32043/gsd.v4i4\%20si.292.

Bruschi B., \& Perissinotto A. (2020). Didattica a distanza. Com’è, come potrebbe essere. Bari: Laterza.

Carbone D., Dagnes J., Barberis E., \& Bazzoli N. (2021). Insegnare durante l'emergenza Covid-19. La didattica a distanza nella fase emergenziale. In A.R. Favretto, A. Maturo \& S. Tomelleri (Eds.), L'impatto sociale del Covid-19 (pp. 352-362). Milano: FrancoAngeli.

Caruana F. (2021). La didattica disembodied. La "Didattica a Distanza" nell'epoca dell'Embodied Cognition. In A. D'Aiola (Ed.), La tempesta del covid. Dimensioni bioetiche (pp. 291-298). Milano: FrancoAngeli.

Lapov Z. (2021). Esperienze di DaD 2020 con alunni di recente immigrazione: punti di forza e debolezza. Pedagogia oggi, 19(1), 42-49. doi10.7346/PO-012021-05.

Limone P., Toto G.A., \& Sansone N. (2020) (Eds.). Qwerty. Didattica universitaria a distanza. Tra emergenze e futuro. Bari: Progedit.

Roncaglia G. (2020). Cosa succede a settembre? Scuola e didattica a distanza ai tempi del COVID-19. Bari: Laterza.

Rucci A. (2020). Il modello blended per la scuola del futuro. Dirigenti Scuola, 39, 168-175.

Sarsini D. (2020). Alcune riflessioni sulla didattica a distanza. Studi sulla Formazione, 23(1), 9-12. doi: 10.13128/ssf-12826

Vinci V. (2020). Didattica digitale in università: luci, ombre, prospettive. Giornale Italiano di Educazione alla Salute, Sport e Didattica Inclusiva, 4, 103 110. doi: https://doi.org/10.32043/gsd.v4i4\%20si.301.

Theoretical reflections \& studies on the use of new technologies

Addeo F., Catone M.F., \& Parziale F. (2020). L'uso delle tecnologie digitali. In C. Lombardo \& S. Mauceri (Eds.), La società catastrofica. Vita e relaz̧ioni sociali ai tempi dell'emergenza Covid-19 (pp. 133-151). Milano: FrancoAngeli.

Agaisti T., \& Di Blas N. (Eds.). Innovare le scuole con la tecnologia. Indicazioni da un'esperienza durante l'emergenza Covid-19 (pp. 29-40). Milano: Guerini Next. 
Aiello A. (2021). Integrare il digitale nella scuola italiana. Nuovi bisogni di formazione. Formazione \& Insegnamento, 19(1-II), 555-569. doi: 10.7346/-fei-XIX-01-21_49.

Annacontini G. (2020). Competenze d'uso e fruizione consapevole. Aspetti intangibili del digital divide. In P. Ellerani \& S. Crisante (Eds.), Le Scienze Umane alla prova della distanza sociale. Ciclo di seminari oline su socializzazione, comunità, relazioni, economia, comunicazione ed educazione (pp. 143-151). doi:10.1285/ixxxxxxxxn1.

Aroldi P. (2021). La survey con gli studenti. In M. Sala (Ed.), Libro Bianco. Media e minori. L'educazione ai nuovi media ai tempi del coronavirus (pp. 95112). Soveria Mannelli: Rubettino.

De Martino D. (2021). E-learning e mondo classico. Educazione. Giornale di pedagogia critica, X(1), 103-126. doi: 10.14668/Educaz_10106

Limone P., \& Toto G.A. (2020). Ambienti di apprendimento digitale e ubiquitous learning: prospettive applicative e di didattica nella scuola post-Covid-19. Dirigenti Scuola, 39, 10-19.

\section{Theoretical reflections on education}

Balzano V. (2021). Crisi economica e crisi educativa. Una nuova idea di welfare sostenibile nella complessità del post Covid-19. Formazione \& Insegnamento, 19(2), 28-39. doi: 10.7346/-fei-XIX-02-21_03.

Cambi F. (2020). Pandemia Covid-19: una breve riflessione pedagogica. Studi sulla Formazione, 23(1), 55-57. doi: 10.13128/ssf-12827.

Elia G. (2021) (Ed.). A scuola di umanità. Teorie e pratiche educative. Bari: Progedit. Lucifora C., \& Cevolani G. (2020). Ethical and cognitive challenges in the COVID-19 emergency. Rivista internazionale di filosofia e psicologia, 11(3), 327-340. doi: 10.4453/rifp.2020.0022.

Paparella N., Limone P., \& Cinella G. (2021). Pandemia. Apprendere per prevenire. Bari: Progedit.

Investigating emotions and the self: theoretical reflections and studies

Antonicelli T., Capriati E., Laforgia A., Porcelli R., Sgaramella A., \& Foschino Barbaro M.G. (2020). Emergenza COVID-19: aspetti psicosociali e buone prassi per promuovere il benessere psicologico. Psicoterapeuti in formazione, Numero speciale Covid-19, 40-55. 
Bagnato K. (2021). The hikikomori phenomenon in Italy at the time of the pandemic: pedagogical implications. Annali online della Didattica e della Formazione Docente, 13(21), 129-149.

Cinque M., \& Ferdinandi M. (2020). Ripensare la scuola: la mindfulness per sostenere l'equilibrio psico-fisico e favorire lo sviluppo cognitivo e socioemotivo nel periodo post-Covid. Dirigenti Scuola, 39, 20-43.

Fabbri M. (2020). Nella crisi, il mutamento, nel disagio, i segni del tempo. Quando la cura chiama la complessità dell'esperienza emozionale. MeTis. Mondi educativi. Temi, indagini, suggestioni, 10(2), 1-12. doi: 10.30557/MT00131.

\section{Care \& relationships}

Folgheraiter F. (2020). Welfarevirus. Brevi lezioni di Metodologia del Lavoro sociale (impartite da un'umanità impaurita). Trento: Erickson.

Mortari L. (2021). La politica della cura. Prendere a cuore la vita. Milano: Raffaello Cortina.

Musaio M. (2020). Dalla distanza alla relazione. Pedagogia e relazione d'ainto nell'emergenza. Sesto San Giovanni: Mimesis.

\section{Resilience}

Bonazzi A. (2020). Resilienza, ascolto e rispetto: la risposta dell'IISS A. Fantoni di Clusone. Dirigenti Scuola, 39, 134-141.

Malaguti E. (2020). Educarsi in tempi di crisi. Resilienza, pedagogia speciale, processi inclusivi e intersezioni. Fano: Aras edizioni.

Marion P. (2020). Resilienza psicologica e pandemie. In C. Caporale \& A. Pirni (Eds.), Pandemia e resilienza. Persona, comunità e modelli di sviluppo dopo la Covid-19. Consulta Scientifica del Cortile dei Gentili (pp. 99-104). Roma: Edizioni CNR. doi: https://doi.org/10.48220/PANDEMIAERESILIENZA-2020.

Pignalberi C. (2021). Promuovere esperienze di apprendimento sul territorio: la sostenibilità e la resilienza. Formazione \& Insegnamento, 19(1-I), 282-295. doi: 10.7346/-fei-XIX-01-21_25.

Zizioli E. (2021). "Resilient education": the schooling system becomes non-formal. Pedagogia oggi, 19(1), 65-71. doi10.7346/PO-012021-08. 
Families (\& unaccompanied minors), protection of minors

Allodi M.D., Fucci S., \& Scivoletto C. (2021). La "tutela minori" e l'impatto del Covid-19. Relazioni e interazioni nelle comunità familiari del parmense. In A.R. Favretto, A. Maturo \& S. Tomelleri (Eds.), L'impatto sociale del Covid-19 (pp. 395-404). Milano: FrancoAngeli.

Balzano V. (2021). Crisi economica e crisi educativa. Una nuova idea di welfare sostenibile nella complessità del post Covid-19. Formazione \& Insegnamento, 19(2), 28-39. doi: 10.7346/-fei-XIX-02-21_03.

Biffi E., \& Galimberti A. (2021). Tutelarsi dall'emergenza: ripensare le pratiche educative nella tutela dei minorenni attraverso l'esperienza della pandemia. Pedagogia oggi, 19(1), 19-27. doi10.7346/PO-012021-02.

Coin F., \& Banzato M. (2021). Minori non accompagnati al tempo del covid-19: la tecnologia digitale rafforza o indebolisce le relazioni?. Formazione \& Insegnamento, 19(1-II), 505-512. doi: 10.7346/-fei-XIX-0121_44.

D’Antone A. (2021). Il sostegno alla famiglia e alla genitorialità: prassi educative tra continuità e discontinuità. In A. Gigli (Ed.), Oltre l'emergenza. Sguardi pedagogici su infanzia, famiglie, serviri educativi e scolastici nel Covid-19 (pp. 51-59). Parma: Edizioni Junior.

Khoory B.J., \& Fanos V. (2021) (Eds.). Famiglie e COVID-19. Come orientarsi. Quartu Sant'Elena: Hygeia Press.

Lajus C. (2021). Esperienza genitoriale in condizioni di povertà assoluta ai tempi del Coronavirus: il racconto di una vita confinata, tra bisogni e segnali di speranza. In A. Gigli (Ed.), Oltre l'emergenza. Sguardi pedagogici su infanzia, famiglie, servizi educativi e scolastici nel Covid-19 (pp. 61-71). Parma: Edizioni Junior.

\section{Sustainability}

Biffi E. (2021). Pensare la sostenibilità in tempi di pandemia: contributi e sfide dalla ricerca educativa. Formazione \& Insegnamento, 19(1-I), 48-59. doi: 10.7346/-fei-XIX-01-21_04.

De Blasis M.C. (2021). La koinè della sostenibilità per l'educazione postCovid-19. Formazione \& Insegnamento, 19(1-I), 352-360. doi: 10.7346/fei-XIX-01-21_31. 
De Giuseppe T., Podovšovnik E., Annarumma M., Ianniello A., \& Corona F. (2021). Flipped Inclusion, tra Complessità pandemiche ed ecosostenibilità didattica. Formazione \& Insegnamento, 19(2), 122-137. doi: 10.7346/-fei-XIX-02-21_12.

Ellerani P. (2021). Le declinazioni della sostenibilità come proposta pedagogica: la prospettiva dello sviluppo umano e delle capacitazioni. Formaz̧ione \& Insegnamento, 19(1-I), 7-11.

Vischi A. (2021). Sostenibilità e imprese per generare il bene comune. Progettualità, Post-Covid 19, Società benefit. Formazione \& Insegnamento, 19(2), 50-56. doi: 10.7346/-fei-XIX-02-21_05.

\section{Disability \& inclusion}

Comunello F., \& Settin M. (2021). Disabilità e bellezza. Generare significato nella relazione con l'Altro. Trento: Erickson.

Fantozzi D. (2020). Solitudine e difficoltà di relazione sociale degli studenti con disabilità al tempo dell'isolamento da Covid-19: dai recinti alle reti di cura. Pedagogia Oggi, 18(2), 154-169. doi: 10.7346/PO022020-12.

Guerrini V. (2021). Studenti e studentesse non italiani/e nella scuola secondaria tra inclusione e rischio di emarginazione. Risultati da una ricerca qualitativa prima e durante la pandemia da Covid 19. Formazione \& Insegnamento, 19(1-II), 459-469. doi: 10.7346/-fei-XIX-01-21_40.

Gulisano D. (2021). L'azione didattica inclusiva del docente: verso una scuola post Covid-19 equa e sostenibile. Formazione \& Insegnamento, 19(2), 237-245. doi: 10.7346/-fei-XIX-02-21_23.

Martiniello L., \& Madonna G. (2020). Pedagogia dell'inclusione: prospettive didattico-sportive ai tempi del Covid-19. Giornale Italiano di Educazione alla Salute, Sport e Didattica Inclusiva, 4, 116-121.

Montesano P., \& Madonna G. (2020). Effetti della pandemia da Covid-19 sui soggetti ciechi. Giornale Italiano di Educazione alla Salute, Sport e Didattica Inclusiva, 2, 68-74. doi: 10.32043/gsd.v4i2.198.

\section{Childhood literacy}

Coppi C.B., \& Baldoni D. (2021). Il re Corona. Aprilia: Aracne.

Dall'Ara F. (2020). Storia di un coronavirus - MAESTRA, COME SI FA?. Trento: Erickson. 


\section{Conclusion}

This study set out to gain a better understanding of Italian academic output in the field of the social sciences, highlighting how current pedagogy «can be measured precisely by its "epistemological resilience", i.e. its ability to interpret and translate concepts and design "capacitating" interventions»" (Pinto Minerva, 2021, p. 341). The interventions and actions undertaken by Italian social scientists are manifold, whether in the theoretical milieu, in designing practical devices or in collecting quantitative data. It appears that the aim of the literature selected is to underline those positive aspects of our condition as human beings, in spite of our «burnout society» (Musaio, 2020, p. 55), and to present consistently positive ways of tackling reality. According to Scardicchio (2020), we are called not to seek the beautiful - «which relates to judgments always within parts that are passed off as whole and therefore at risk of totalitarianism $\rangle^{20}-$ but the beauty (p. 19). Proactive activities pursued by scholars might be examples not only of subjects for further investigation but of practical tools for students, educational practitioners, teachers and families.

\section{References}

Annaconti G. (2021). Autocoscienza in formazione. In M. Ceruti (Ed.), Cento Edgar Morin. 100 firme italiane per i 100 anni dell'umanista planetario (pp. 77-79). Sesto San Giovanni: Mimesis.

Annacontini G., \& Dato D. (2020). Dove abita la pedagogia. In G. Annacontini \& D. Dato, Pedagogia dei contesti. Spazi, tempi, esperienze dell'educare contemporaneo (pp. VII-XIV). Bari: Progedit.

Bertagna G. (2020). La scuola al tempo del Covid. Tra spazio di esperienza ed orizzonte d'attesa. Roma: Studium Edizioni.

${ }^{19}$ Original text: "[...] il ruolo della pedagogia si misura proprio sulla sua 'tenuta epistemologica', ovvero sul suo riuscire a interpretare e tradurre a livello di concetti e di progettazione di interventi 'capacitanti"'.

${ }^{20}$ Original text: "Che attiene a giudizi sempre dentro parti che si spacciano per intero, e dunque a rischio di totalitarismi”. 
Cambi F. (2021). Un pensiero plurale per abitare il tempo presente. In M. Ceruti (Ed.), Cento Edgar Morin. 100 firme italiane per $i 100$ anni dell'umanista planetario (pp. 131-132). Sesto San Giovanni: Mimesis.

Contini A. (2021). Prefazione. "Tentazioni virali": prima, durante, dopo. In A. Gigli (Ed.), Oltre l'emergenza. Sguardi pedagogici su infanzia, famiglie, servizi educativi e scolastici nel Covid-19 (pp. 9-13). Parma: Edizioni Junior.

Dozza L. (2020). Prefazione. In M. Cagol, Emozioni, ragione, etica in educazione. Per una pedagogia di comportamenti complessi (pp.7-11). Milano: FrancoAngeli.

Gigli A. (2021). Introduzione. In A. Gigli (Ed.), Oltre l'emergenza. Sguardi pedagogici su infanzia, famiglie, servizi educativi e scolastici nel Covid-19 (pp. 15-25). Parma: Edizioni Junior.

Gigli A. (2021) (Ed.). Oltre l'emergenza. Sguardi pedagogici su infanzia, famiglie, servizi educativi e scolastici nel Covid-19. Parma: Edizioni Junior.

Han B.C. (2020). La società senza dolore. Perché abbiamo bandito la sofferenza dalle nostre vite. Torino: Einaudi.

Harris D.J. (2020). Literature Review and Research Design: A Guide to Effective Research Practice. New York: Routledge.

Husserl E. (1931/2004). Meditazioni cartesiane. Roma: Armando.

Isidori M.V., \& Vaccarelli A. (2013). Pedagogia dell'emergenza. Didattica dell'emergenza. I processi formativi nelle situazioni di criticità individuali e collettive. Milano: Franco Angeli.

Lévinas E. (2002). Dall'altro all'io. Roma: Meltemi.

Mannese E. (2021). Una "pedagogia dinamica", nella policrisi. In M. Ceruti (Ed.), Cento Edgar Morin. 100 firme italiane per $i 100$ anni dell'umanista planetario (pp. 275-277). Sesto San Giovanni: Mimesis.

Mariani A. (2021). Lectio pedagogica. In M. Ceruti (Ed.), Cento Edgar Morin. 100 firme italiane per $i 100$ anni dell'umanista planetario (pp. 49-51). Sesto San Giovanni: Mimesis.

Mariani Zini F. (2009). Bibliografia ragionata. In E. Franzini, \& M. Mazzocut-Mis, Estetica: I nomi, i concetti, le correnti (pp. 373-456). Milano: Mondadori.

Montuori A. (2019). Creating Social Creativity: Integrative Transdisciplinarity and the Epistemology of Complexity. In I. Lebuda \& V.P. Glăveanu (Eds.), The Palgrave Handbook of Social Creativity Research (pp. 407-430).

Morin E. (2000). La testa ben fatta. Riforma dell'insegnamento e riforma del pensiero. Milano: Raffaello Cortina. 
Morin E. (2001). I sette saperi necessari all'educazione del futuro. Milano: Raffaello Cortina.

Morin E. (2020). Cambiamo strada. Le 15 lezioni del Coronavirus. Milano: Raffaello Cortina.

Morin E. (2021a). La sfida della complessità. Firenze: Le Lettere.

Morin E. (2021b). L'uomo e la morte. Trento: Il Margine: Trento.

Mortari L. (2008) The ethic of delicacy in phenomenological research. International Journal of Qualitative Studies on Health and Well-being, 3(1), 3-17. doi: 10.1080/17482620701747392

Mortari L. (2017). La sapienza del cuore. Pensare le emozioni, sentire i pensieri. Milano: Raffaello Cortina.

Mortari L. (2019). Aver cura di sé. Milano: Raffaello Cortina.

Mortari L., \& Mazzoni V. (2010). Rassegna bibliografica infanz̧a e adolescenza. Firenze: Istituto degli Innocenti.

Mortari L., \& Camerella A. (2014). Fenomenologia della cura. Napoli: Liguori.

Musaio M. (2020). Dalla distanza alla relazione. Pedagogia e relazione d'aiuto nell'emergenza. Sesto San Giovanni: Mimesis.

Pinto Minerva F. (2021). Un paradigma educativo. In M. Ceruti (Ed.), Cento Edgar Morin. 100 firme italiane per i 100 anni dell'umanista planetario (pp. 339-341). Sesto San Giovanni: Mimesis.

Scardicchio A.C. (2020). Metabolé. Speranza, resilienza, complessità. Milano: FrancoAngeli.

Seale C. (2002). L'uso del computer nell'analisi dei dati qualitativi. In D. Silverman, Come fare ricerca qualitativa (pp. 223-248). Roma: Carrocci.

Tedesco S. (1750/2020). Presentazione. In A.G. Baumgarten, Estetica (pp. 7-18). Sesto San Giovanni: Aestethica Edizioni. 